Pérez AR, Gonçalves LS, Antunes FE, Siqueira JF Jr, Rôças IN. / J Endod. 2018. Oct. № 44(10). P. 1593-1597.

6. Persistent extra-radicular bacterial biofilm in endodontically treated human teeth: scanning electron microscopy analysis after apical surgery. Sousa BC, Gomes FA, Ferreira CM, Rocha MMNP, Barros EB, Albuquerque DS. / Microsc Res Tech. 2017. Jun. № 80(6). P. 662-667.

DOI https://doi.org/10.30525/978-9934-26-038-4-37

\title{
ЗНАЧЕНИЕ РИГИДНОСТИ ЭРИТРОЦИТОВ В РАЗВИТИИ МИКРО-АНГИОПАТИИ У БОЛЬНЫХ С САХАНЫМ ДИАБЕТОМ 2 ТИПА
}

\author{
Сморжевський В. И. \\ доктор медицинских наук, \\ профессор кафедры хирургии и трансплантологии \\ Национальная медицинская академия последипломного образования \\ имени П. Л. Шупика, \\ Национальный институт хирургии и трансплантологии \\ имени А. А. Шалимова \\ Манасрах Рашид X. P. \\ аспирант кафедры хирургии и трансплантологии \\ Национальная медицинская академия последипломного образования \\ имени П. Л. Шупика, \\ Национальный институт хирургии и трансплантологии \\ имени А. А. Шалимова \\ Свиридов Н. В. \\ доктор медицинских наук, \\ главный научный сотрудник отдела эндокринной хирургии, \\ заведуюший отделением диабетической стопь \\ Diabetic foot center-Kyiv \\ г. Киев, Украина
}

Реологические параметры (от греч. rhe'os - течение, поток) - это свойства крови, связанные с ее текучестью. Если в крупных сосудах наибольший вклад в движение тока крови вносят инерционные силы, связанные с массой, то в микрососудистом русле на движение тока крови в большей степени влияют ее реологические свойства. Это свя- 
зано с наличием здесь наибольшего сопротивления кровотоку, обусловленного архитектоникой русла. Реологические свойства крови в основном зависят от вязкости крови - интегрального параметра, определяющего текучесть крови. Принципиальными факторами, влияющими на вязкость цельной крови, являются объемная концентрация форменных элементов в плазме, свойства плазмы, агрегация и деформируемость клеточных элементов.

Поскольку количество эритроцитов в кровяном русле во много раз превосходит количество других форменных элементов (и составляет 93-98\% общего числа), реологические свойства, в том числе вязкость крови, в наибольшей степени определяются объемной концентрацией эритроцитов. Таким образом, вязкость крови зависит от величины гематокрита, вязкости плазмы, а также от способности эритроцитов к агрегации и деформации .

Ранняя инвалидизация и летальность больных сахарным диабетом (СД), причиной которых, как правило, являются диабетические ангиопатии, представляет собой важнейшую медико-социальную проблему современной диабетологии [1]. Своевременное выявление микроциркуляторных нарушений, коррекция гемореологических расстройств в настоящее время признается в качестве значительного компонента современной диагностической и лечебной тактики в отношении больных с СД. Микрореологические свойства эитроцитов, такие как деформируемость, агрегационная способность и генерация вазореактивных факторов, определяются особенностями молекулярной организации эритроцитарной мембраны и примембранного цитоплазматического матрикса .

Поляризуемость клеток, уровень гемолиза и агрегации связаны с измененными условиями процессов созревания клеток красной крови, демонстрируют их сниженную стойкость к действию различных факторов, что впоследствии скажется на взаимодействии с клетками измененного эндотелия.

Таким образом, ригидность эритроцитов, измеряемые методом АСМ (атмно-силовой микроскопии), позволяют дать ценную информацию, которая имеет непосредственное отношение к развитию нарушений реологии при СД.

Наши исследовании показывают, что атомно-силовая микроскопия может быть многообещающим инструментом для выявления нарушении микроциркулятурного русла при сахарном диабете 2 типа.

Цель настоящей работы: представить возможности диагностики нарушений реологии у пациентов с СД 2 типа, основанные на измерении ригидность и вязкоупругих параметров эритроцитов методом ACM. 
Материалы и методы:

Обследовано 12 пациентов в возрасте $(58,7 \pm 1,6$ лет) с СД 2 типа, из них 3 (25\%) женщины и 9 (75\%) мужчин. Группа сравнения состояла из 4 обследуемых в возрасте 48,5 \pm 2 ,2года - 2 (50 \%) женщины и 2 (50 \%) мужчины без СД и какой-либо другой манифестирующей патологии внутренних органов, обратившихся с профилактической целью (1-я группа).

Пациентам проведено комплексное клиническо-инструментальное обследование, включая ЭКГ, УЗИ органов брюшной полости, почек, сердца и сосудов, определение гликозилированного гемоглобина, альбумин/креатинин-соотношения в разовой порции мочи.

Исследование вязкоупругих параметров эритроцитов проведено методом атомно-силовой микроскопии (АСМ).
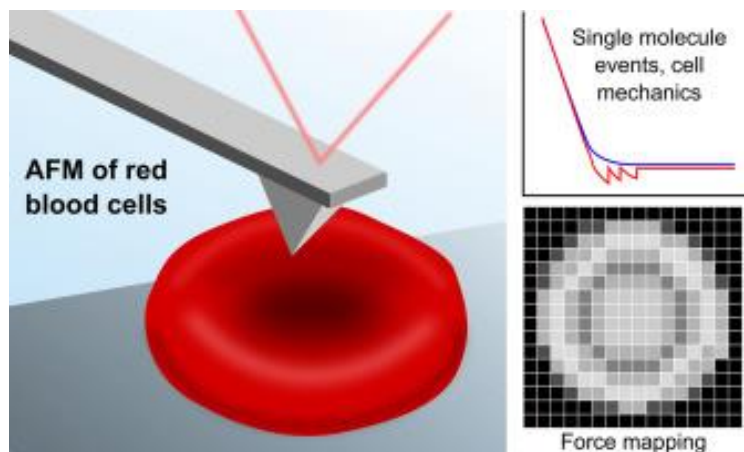

ACM.

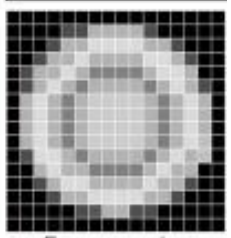

Force mapping принцип работы

Результаты и обсуждение:

В соответствии с критериями оценки риска развития сосудистых осложнений у пациентов СД 2 типа, предложенных Европейской диабетической ассоциацией (EASD, 2013), пациенты с СД 2 типа были разделены на 2 группы - со средним риском поражения мелких сосудов (средняя степень реологических - микроциркуляторных нарушений) 2-я группа $(\mathrm{n}=7)$ с высоким риском микроциркуляторных нарушений 3-я группа $(\mathrm{n}=5)$. Показатели пациентов указанных групп оказались в пределах значений, соответствующих риску поражения крупных и мелких сосудов.

Данные клинико-инструментальных обследований групп представлены . Не установлено достоверных различий по возрасту, полу, стилю потребления алкоголя, курению в группах пациентов с СД 2 типа. Однако в группе с высокой степенью реологических нарушений (3-я группа) оказались достоверно более длительными стаж СД, продолжи- 
тельность артериальной гипертензии, чаще выявлялся семейный анамнез ранних сердечно-сосудистых заболеваний, наличие ИБС с инфарктами миокарда в анамнезе. У пациентов 3-й группы оказались более высокими, чем во 2-й группе, цифры систолического и диастолического артериального давления, чаще отмечены нарушения ритма, проводимости сердца $(\mathrm{p}=0,048)$. Все пациенты с СД 2 типа получали сахароснижающую терапию, направленную на достижение целевых параметров контроля углеводного обмена, антигипертензивные средства.

Пациенты с высокой степенью реологических нарушений оказались более тяжелыми по выраженности проявлений СД 2 типа и его осложнений: в данной группе оказались более высокими уровни гликемии натощак $(9,62 \pm 0,69$ против $7,94 \pm 0,33$ во второй группе, $\mathrm{p}=0,018)$, гликозилированного гемоглобина, альбумин/креатинин-соотношения в разовой порции мочи, более значительными проявления гиперлипидемии (с преобладанием ГЛП 2Б типа), нарушения пуринового обмена, функции печени, выделительной функции почек.

Стоит отметить, что пациенты с выраженными нарушениями реологии имели индекс массы тела (35-45), большую выраженность диабетической нейропатии, ретинопатии (у $60 \%$ больных выявлены пролиферативная ретинопатия), ангиопатии (в 53,3 \% случаях она соответствовала ІІБ степени, когда боли в нижних конечностях возникали при ходьбе менее 200 метров).

Анализ параметров красной крови не выявил наличие достоверных различий в группах по количеству эритроцитов, уровню цветового показателя и гемоглобина. Вместе с тем установлено, что пациенты с СД 2 типа имели повышенный гематокрит, большую ширину распределения эритроцитов по объему, а средний корпускулярный объем, среднее содержание гемоглобина в эритроците оказались ниже, чем у здоровых лиц.

Известно, что деформируемость клеток красной крови обусловлена их вязкоупругими характеристиками. По результатам настоящего исследования, выявлено снижение способности эритроцитов к деформации на фоне нарастания обобщенных показателей вязкости и жесткости клеток. Данные сдвиги могут быть связаны с повышением содержания холестерина в мембране эритроцитов, увеличением индекса холестерин/фосфолипиды. 


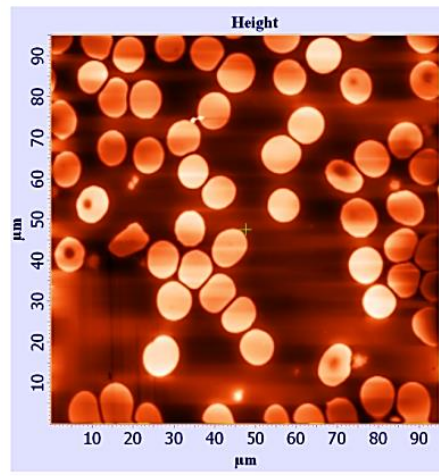

A

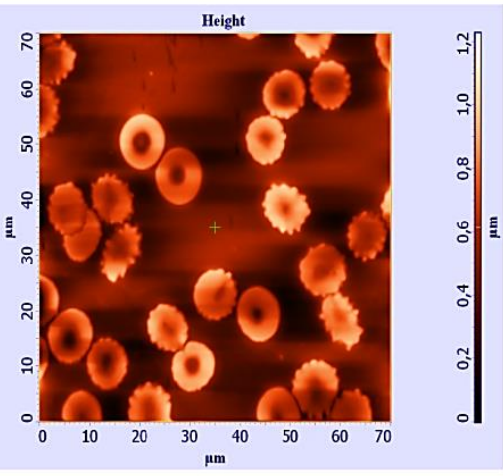

B

эритроцитов под $\mathrm{ACM}$ : A - у здоровых лиц; $\mathrm{B}$ - у пациентов с СД.

Заключение:

Получены данные сведительствуют о том что обширные области капиллярного русла оказываются «выключенными» из кровотока и кислородного обмена, поскольку агрегаты и ригидные эритроциты не способны пройти через капиллярного русла.

Изучение ригидность эритроцитов методом АСМ позволяет получить информацию о деформации эритроцитов и ее значение в развитии микроангиопатии при сахарном диабете 2 типа.

Дальнейшие изучение ригидность эритроцитов может позволить выбрать оптимальное медикаментозное лечение данной патологии.

\section{Литература:}

1. Lavigne J.-P. New Molecular Techniquesto Study the Skin Microbiota of Diabetic Foot Ulcers / J.-P. Lavigne, A. Sotto, C. Dunyach-Remy [et al.] Adv. WoundCare (NewRochelle). - 2015. - Vol. 4. №. 1. - P. 38-49.

2. Кравец Е.Б. Молекулярные нарушения мембраны эритроцитов при сосудистых осложнениях сахарного диабета / Е.Б. Кравец, Р.Т. Тухватулин, Н.В. Рязанцева [и др.] // Сахарный диабет. - 2006, № $1 .-$ C. $10-14$.

3. Cho Y.I. Hemorheological disorders in diabetes mellitus / Y.I. Cho, M.P. Mooney, D.J. Cho // J. Diab. Sci. \&Technol. - 2008. Vol. 2. - P. 1130-1138.

4. Ryden L. The task force on diabetes, pre-diabetes, and cardiovascular diseases of the European Society of Cardiology (ESC) and developed incollaboration with the European Association for the study of diabetes (EASD) / L. Ryden, P.J. Grant, S.D. Anker, [et al.] // European Heart Journal. 2013. - Vol. 34. - P. 3035-3087. 
5. Новицкий В.В. Физиология и патофизиология эритроцита / В.В. Новицкий, Н.В. Рязанцева, Е.А. Степовая. - Томск: Из-воТГУ, 2004. - 202 с.

6. Козинец Г.И. Кровь: стабильность, консерватизм и память гемопоэза / Г.И. Козинец, В.В. Высоцкий, С.А. Луговская // Вестник службы крови России. - 2012. - № 2. - С. 20-27.

7. Murav'ev A.V., Tikhomirov I.A., Mikhaylov P.V., Muravieva A.A. Haemorheology and microcirculation: a textbook. Yaroslavl', 2010.

DOI https://doi.org/10.30525/978-9934-26-038-4-38

\title{
КЛІНІЧНІ ОСОБЛИВОСТІ АНОМАЛЬНИХ МАТКОВИХ КРОВОТЕЧ У ЖІНОК В СТАНІ ХРОНІЧНОГО СТРЕСУ
}

\author{
Федосюк К. В. \\ аспірант кафедри акушерства, гінекологї та репродуктології \\ Національний університет охорони здоров'я Украӥни \\ імені П. Л. Шупика \\ м. Київ, Україна
}

За даними науковців майже $30 \%$ жінок мали в своєму житті розлади менструального циклу різного характеру [3]. Такі порушення можуть проявлятись у вигляді нерегулярного циклу, зміні частоти менструальних кровотеч, різної тривалості та об'єму менструальних виділень. Аномальна маткова кровотеча (АМК) є частим розладом, який діагностується у жінок всіх вікових категорій - від підлітків, жінок репродуктивного віку та осіб в менопаузі. Вважають, що 10-30 \% жінок репродуктивного віку та біля 90 \% в перименопаузі зустрічались 3 даною патологією [2]. Причинами виникнення АМК можуть бути аденоміоз, фіброміома матки, поліпи порожнини матки, гіперплазія ендометрію, злоякісні пухлини та ін. $[4,5]$. Часто психологічні фактори $є$ підгрунтям перебігу даного процесу.

Метою нашого дослідження було встановити клінічні особливості аномальних маткових кровотеч у жінок в стані хронічного психоемоційного стресу.

Методи дослідження. У дослідження увійшло 100 жінок репродуктивного віку з АМК, які знаходились в стані хронічного стресового навантаження. Ці жінки становили основну групу. 30 жінок репродуктивного віку з АМК без факторів хронічного психоемоційного стресу становили групу порівняння. Діагноз АМК та її вид встановлювали на 